4. Andrukhovych Yu. (2015). Tut pokhovanyi Fantomas [The phantom is buried here] Brusturiv: Dyskursus. 240 p. [In Ukrainian].

5. Berhson A. (1998). Tvorcheskaia evoliutsyia [Creative evolution]: per. s frants. Moskva: KANON-press; Kuchkovo pole, 384 p. [In Russian].

6. Dzharmush D. (1987/2007) V promezhutke. P. fon Bakh y M. Kaurysmiaky / 1987. [In the interval. P. fon Bakh and M. Kaurismaki / 1987]. Dzharmush Dzhym: ynterviu [Jarmusch Jim: interview]. Sostavytel L. Khertsberh. Per. S anhl. E. Burmystrovoi, A. Brahynskoho. SPb.: Azbuka-klassyka, 352 p. URL: http://booksonline.com.ua/view. php?book=146577\&page $=2$ [In Russian].

7. Dzharmush D. (2000/2007). Vostok y Zapad. K. Kempyon / 2000. [East and west. K. Kampion / 2000]. Dzharmush Dzhym: ynterviu [Jarmusch Jim: interview]. Sostavytel L. Khertsberh. Per. s anhl. E. Burmystrovoi, A. Brahynskoho. SPb.: Azbuka-klassyka, 352 p. URL: http://booksonline.com.ua/view.php?book=146577\&page=2 [In Russian].

8. Delez Zh. (1996). Lohyka smysla [Logic of meaning]. Moskva: Akademyia. 346 p.[In Russian].

9. Dzharmush D. (1999/2007). Dzheff Endriu / 1999. [Jeff Andrew / 1999]. Dzharmush Dzhym: ynterviu [Jarmusch Jim: interview]. Sostavytel L. Khertsberh. Per. s anhl. E. Burmystrovoi, A. Brahynskoho. SPb.: Azbuka-klassyka, 352 p. URL: http://booksonline.com.ua/view.php?book=146577\&page=2 [In Russian].

10. Dzharmush D. (1996/2007). Konets puty. Skott Makolei [The end of the road. Scott Macaulay / 1996]. Dzharmush Dzhym: ynterviu [Jarmusch Jim: interview]. Sostavytel L. Khertsberh. Per. s anhl. E. Burmystrovoi, A. Brahynskoho. SPb.: Azbukaklassyka, 352 p. URL: http://booksonline.com.ua/view.php?book=146577\&page=2 [In Russian].

11. Lakan Zh. (2008). Yznanka psykhoanalyza [The wrong side of psychoanalysis] (Semynar, Knyha XVII (1969/70)). M. : Hnozys/Lohos. 272 p. [In Russian].

12. Lykholetova O. R. (2019). Kontsept « $\square \mathrm{MA}$ » y sposoby eho reprezentatsyy v yaponskom yazyke. [Concept «MA» and the ways of its representation in Japanese]. Fylolohycheskye nauky v MHYMO. №3. Pp. 92-99. URL: https://philnauki.mgimo. $\mathrm{ru} /$ jour/article/view/224/225 [In Russian].

13. Mazurak A. (2012). Pro vrodzhenu «kinematohrafichnist» khudozhnoi literatury dokinematohrafichnoho periodu. [About the inherent «cinematographic» artistic literature of the pre-nematographic period]. Naukovi zapysky. Seriia «Filolohichni nauky (Literaturoznavstvo)» Vyp. 111. Pp. 137-156 [In Ukrainian].

14. Martianova Y. A. (2002) Kynovek russkoho teksta. Paradoks lyteraturnoi kynematohrafychnosty. [Cinematic century of the Russian text. The paradox of literary cinematography.] SPb: SAHA. 240 p. [In Russian].

15. Nansy Zh-L. (1999) Corpus. Sost., obshch. red. y vstup. st. E. Petrovskoi. Moskva: Ad Marginem, 255 p. [In Russian].

16. Punina O. V. (2011). Zasoby kino movy v ukrainskii khudozhnii prozi 20-30-kh rokiv XX stolittia [Means of cinema language in Ukrainian fiction of the 20s and 30s of the XX century]: avtoref. dys. ... kand. filol. nauk: 10.01.06. Donetsk, 19 p. [In Ukrainian].

17. Tiazhlov Ya. (2013). Chetyre yazyka Otara Yoselyany. Sovremennyi dyskurs-analyz [Otar Ioseliani's four languages. Contemporary discourse analysis]. №10. URL: http://discourseanalysis.org/ada10.pdf [In Russian].

18. Fuko M. (1994). Slova y veshchy. Arkheolohyia humanytarnykh nauk. [Words and things. Archeology of the Humanities.] Per. S frants. V. P. Vyzghyna, N. S. Avtonomovoi. SPb.: A-cad. 407 p.

19. Tournier M. Vendredi ou Les limbes du Pacifique. URL: https://flipbook.cantook.net/?d=\%2F\%2Fwww.edenlivres.

DOI https://doi.org/10.51647/kelm.2020.4.1.24

ПРОБЛЕМА СУТНОСТІ ЗЛА У ТВОРЧОСТІ МИТРОПОЛИТА СУРОЗЬКОГО АНТОНІЯ

\author{
Михайло Сивак \\ кандидат богослов'я, доиент, \\ доцент кафедри біблійних та філологічних дисциилін \\ Львівської православної богословської академії (Львів, Україна) \\ ORCID ID: 0000-0003-0120-1368
}

\begin{abstract}
Анотація. Ця стаття присвячена темі осмислення проблематики зла видатним християнським мислителем і богословом митрополитом Сурозьким Антонієм (Блумом). Владика Антоній тривалий час працював лікарем. I тому його осмислення феномена зла збагачене не лише богословським досвідом, а й медико-практичним.

Об 'єктом наукової статті є богословська та релігійно-філософська думка митрополита Антонія Сурозького.

Предметом дослідження є онтологічний аспект категорії зла в її інваріантних проявах у філософській і релігійній парадигмах філософсько-теологічної думки митрополита Антонія Сурозького.

Основною метою дослідження є здійснення історико-філософського аналізу категорії зла в їі онтологічному аспекті на матеріалі філософських і теологічних концепцій митрополита Антонія Сурозького.
\end{abstract}

Ключові слова: зло, природа, реальність, особистість, позиція, антропологія, сутність. 


\title{
THE ESSENCE OF EVIL PROBLEM IN THE WORKS OF METROPOLITAN ANTHONY OF SOUROZH
}

\author{
Syvak Mykhailo \\ Candidate of Theology, Associate Professor, \\ Associate Professor at the Biblical and Philological Disciplines \\ Lviv Orthodox Theological Academy (Lviv, Ukraine) \\ ORCID ID: 0000-0003-0120-1368
}

\begin{abstract}
This article is devoted to the theme of understanding of the evil problems by Metropolitan Anthony of Sourozh (Bloom), an outstanding Christian thinker and theologist. Bishop Antony worked as a doctor for a very long time. Therefore, his understanding of the evil phenomenon is enriched not only by theological experience, but also by the one of medical practice.

The object of the scientific article is the theological thought of Metropolitan Anthony of Sourozh.

The subject of the study is the ontological aspect of the category of evil in its invariant manifestations in the philosophical and religious paradigms of the philosophical and theological thought of Metropolitan Anthony of Sourozh.

The main purpose of the study is to carry out a historical and philosophical analysis of the category of evil in its ontological aspect based on the philosophical and theological concepts of Metropolitan Anthony of Sourozh.

Key words: evil, nature, reality, personality, position, anthropology, essence.
\end{abstract}

\section{PROBLEM ISTOTY ZLA W TWÓRCZOŚCI METROPOLITY SUROSKIEGO ANTONIEGO}

\author{
Mykhailo Syvak \\ kandydat nauk teologicznych, docent, \\ docent Katedry Dyscyplin Biblijnych i Filologicznych \\ Lwowskiej Prawosławnej Akademii Teologicznej (Lwów, Ukraina) \\ ORCID ID: 0000-0003-0120-1368
}

\begin{abstract}
Adnotacja. Niniejszy artykuł poświęcony jest tematyce pojmowania problematyki zła przez wybitnego myśliciela chrześcijańskiego i teologa metropolitę Suroskiego Antoniego (Blooma). Pan Antoni przez długi czas pracował jako lekarz. Dlatego jego rozumienie zjawiska zła jest wzbogacone nie tylko doświadczeniem teologicznym, ale także medyczno-praktycznym.

Obiektem artykułu naukowego jest myśl teologiczna i religijno-filozoficzna metropolity Suroskiego Antoniego.

Przedmiotem badań jest ontologiczny aspekt kategorii zła w jej niezmiennych przejawach w filozoficznych i religijnych paradygmatach myśli filozoficzno-teologicznej metropolity Antoniego Suroskiego.

Głównym celem niniejszego badania jest przeprowadzenie analizy historyczno-filozoficznej kategorii zła w jej aspekcie ontologicznym na materiale koncepcji filozoficznych i teologicznych metropolity Antoniego Suroskiego.

Słowa kluczowe: zło, natura, rzeczywistość, osobowość, pozycja, antropologia, istota.
\end{abstract}

Вступ. Питання походження та існування у світі зла, а також пов'язаної з ним проблеми теодицеї, можна назвати одним із найактуальніших у всі часи існування людства. Видатний християнський мислитель О. Шмеман так описує проблематичність цієї теми: «Наша епоха особливо відзначена ненаситним жаданням знайти нарешті засіб від зла і страждання. Чому у світі так багато зла? Не тільки невіруючі, а й віруючі - ті з них, хто серйозно замислюються над питаннями віри, - часто висловлюють такий сумнів: «Якби Бог існував, хіба допустив би Він таке панування зла у світі протягом тисячоліть?... хіба Він допустив би все це? Допустив би це переповнююче світ страждання: приватне і колективне, ці нещастя, хвороби, жах розлуки і смерті, нескінченне торжество несправедливості, ненависті і насильства?»» (Шмеман, 2009).

Основна частина. Відповідь на це питання людство шукало ще 3 давніх часів. Так, давньогрецький філософ Епікур (IV-III ст. до Р.Х.) висловлює такі міркування: «Бог або хоче знищити зло і не може, або може, але не хоче, або не хоче і не може, або хоче й може. Якщо він може і не хоче, він - заздрісний, що не притаманне богу. Якщо він хоче і не може, він - безсилий, що також не відповідає богу. Якщо ж він не хоче і не може, то він і заздрісний і безсилий. Якщо ж він і хоче і може, що тільки і личить богу, то звідки зло і чому він його не знищує?» (Епікур, Фрагмент 374). Надалі це питання також не втрачало актуальності і було предметом дослідження багатьох мислителів, найбільш значимими в цьому контексті можна вважати ідеї Аристотеля, Тертуліана, Августина Аврелія, Т. Аквінського, І. Канта, Г. Гегеля, А. Шопенгауера, Ж.-П. Сартра, М. Бубера, А. Бадью, Д. Франкла, В. Соловйова, П. Флоренського, М. Лоського, В. Малахова, О. Хоми та ін., які осмислювали проблему зла в різних аспектах.

У XX ст. найбільш глибинно феноменом зла займалися екзистенціалісти, а серед них - Ж-П. Сартр i М. Гайдеггер. I це зрозуміло: їм випало на долю жити в першій половині XX ст.: в епоху великих диктатур, світових воєн, таборів смерті, геноцидів, масових депортацій - епоху нескінченних і безвинних людських страждань. Ж-П. Сартр у своїх творах «Буття і ніщо», «Нудота», «Диявол і милосердний Бог» повстає проти існування зла і страждання. Він тлумачить людське життя як абсурд, даремну муку. М. Гайдеггер, подібно 
до С. К'єркегора, вважає екзистенційну тривогу відчуттям фундаментальної ситуації Dasein (тобто ситуації людини). Ця тривога провокується свідомістю нікчемності «буття-в-світі», трагічної вкиненості у світ.

Проблему страждання гостро ставили письменники, наприклад, Ф. Достоєвський у «Братах Карамазових» або А. Камю в романі «Чума». Насправді, ці автори стурбовані не стільки проблемою страждання і зла, - як свідчить К. Вальверде, - скільки тим, як існування Бога-Творця і Промислителя узгоджується 3 наявністю зла, та ще й такою кількістю зла (Вальверде, 2001: 334), себто проблемою теодицеї.

У контексті сказаного вище В. Лоський справедливо проблему зла називає «проблемою за своєю суттю християнською. Для атеїста зрячого зло - тільки один з аспектів абсурду, для атеїста сліпого воно є тимчасовим результатом ще недосконалої організації суспільства і світу. У моністичній метафізиці зло є невід’ємним визначенням створеного, як розлученого з Богом; але тоді воно не що інше, як ілюзія. У метафізиці дуалістичній воно є «інше», та зла матерія або зле начало, які, однак, співвічні Богу. Таким чином, проблема власне зла сама по собі виникає з християнського вчення. Дійсно, як пояснити наявність його у світі, створеному Богом, у тому баченні, в якому створене по суті своїй $є$ добро? I, навіть враховуючи даровану людині свободу противитися Божественному плану, ми не можемо не ставити собі питання: що таке зло?» (Лосский, 2009: 437).

У своїх бесідах А. Сурозький неодноразово порушує проблему походження зла. Зокрема, в «Бесіді про Символ віри» владика говорить, що «Бог зла не створив. Бог створив світ усією любов’ю Своєю, всією вірою Своєю, всією надією Своєю. Він створив цей світ для того, щоб цей світ і Сам Бог були один одному рідні, щоб Божественна присутність пронизувала все, як жар пронизує залізо, щоб все було живе Ним, щоб, як каже апостол Павло, ми жили, рухалися, були в Ньому (Діян 17:24). Бог створив світ, і в завершення кожного дня, - продовжує владика Антоній, - цього творіння за біблійною оповіддю було таке: I побачив Бог, щзо все добро (Бут 1:31). I в кінцевому підсумку створена людина теж як щось добре» (т. 2. с. 257). А. Сурозький навів цитати з Біблії, в яких показав, що світ був створений добрим, людина створена доброю і жодних натяків на створення чи присутність зла в описі акту творіння ми не знаходимо. Однак для розуміння того, як все-таки зло виникло і увійшло у світ, він спочатку розглядає стан едемської людини в контексті iї призначення. Зокрема, А. Сурозький зазначає, що коли людина була створена, то часто використовується словосполучення «створена досконалою», притім «коли ми вживаємо це слово - «досконалий», - продовжує митрополит, - ми відразу думаємо про святість, про таку велич духа і таке богоспілкування, які є результатом граничного подвигу з'єднання з Богом. Людина була створена досконалою в тому сенсі, що в ній не було тоді ні плями, ні пороку, вона була невинною, гріха в ній не було, зла не було в ній. У цьому відношенні, так, вона була досконалою. Але вона не була досконалою в тому сенсі, ніби в момент свого створення людина дійшла уже до тієї святості і тієї глибини богоспілкування, яка є межею ії покликання. Цей момент дуже важливий, бо не святість людська була підірвана гріхом, а її невинність була обманута злом. І людина злою до кінця не стала, вона виявилася заплутаною, як один з отців Церкви говорить, вона виявилася наче сп'янілою злом» (Сурожский, 2004: 257).

А. Сурозький, слідуючи християнській традиції, виводить виникнення зла 3 ангельського світу, тобто 3 моменту падіння Люцифера. Визначаючи сам алгоритм падіння, саму природу процесу виникнення зла, владика посилається на міркування святителя Григорія Палами, який говорить, що кожен ангел прозорий, як дорогоцінний камінь, в нього ллється світло Боже, і через нього це світло ллється і далі на все творіння. Але, крім того, цей дорогоцінний камінь наче огранований, і світло Боже, яке падає на нього, не тільки через нього проливається, але ще через ці ограни ллється на всі боки. І світло в ангела - це його початкова чистота, досконалість, гармонія, які вміщують, приймають у себе світ Божий і щедро, не утримуючи нічого для себе, віддають це світло, це сяйво Боже всьому створінню (Сурожский, 2004: 258). Так само владика Антоній цитує давньохристиянського письменника Лактанція: «Ангели, як всі інші творіння, мали переходити від слави до слави, тобто виростати все більше, більше, більше, заглиблюватися досконаліше в Бога, відкриватися Йому досконаліше, робитися досконаліше причасниками Його природи. I для цього потрібні, 3 одного боку, повна спрямованість до Бога, а, з іншого боку $-<\ldots$..> готовність втратити ту досконалість, яка у тебе $\epsilon$ і якою ти насолоджуєшся, яка тебе радує, від якої радіє твоє серце. Від неї треба відмовитися для того, щоб рухатися ніби в невідомість, хоча ти знаєш, що, по суті, це не невідомість, бо ця невідомість - Божественна любов, яка тобі все більше відкривається (Сурожский, 2004: 258).

Далі А. Сурозький продовжує, що в «якийсь момент деякі ангели задивилися на себе, подивилися на себе і побачили свою незбагненну красу і злякалися іiї втратити заради того, щоб іiі перерости. Вони забули в той момент, що вся ця краса, все це сяйво, яке в них, - Боже сяйво, воно їм не належить. В той момент, задивившись на себе, Люцифер, світлоносець, подумав: я ж так досконалий, я такий прекрасний, в мені живе все Божественне (в цьому він собі віддавав звіт, це він відчував), чому я не подібний до Бога, чому я нижче його, коли я весь пронизаний Божеством і весь сіяю цим світлом Божества? I, як сказано в одному місці Святого Письма, він сказав: поставлю свій престол на висоті і буду подібний до Бога (Вих. 14:13). I в цей момент світло, яке в ньому було, згасло, тому що це світло було не його світло, це була Божа присутність. I коли він вибрав себе замість Бога, він став з ангела світла ангелом темряви» (Сурожский, 2004: 258). Тобто А. Сурозький вбачає причину виникнення зла (розглядаючи християнську оповідь про падіння у ангельському світі) в тому, що Люцифер, побачивши в собі Божественне сяяння, що є реальністю, помислив, що це сяяння є його власним, що є нереальністю. Тобто зло - це стан нереальності. І далі, говорячи про зло на прикладі спокушення брехнею людини, митрополит Антоній каже: «Брехня полягає в тому, щоб відкинути істину і замість неї поставити щось нереальне, тобто змусити людей думати, що реальність - нереальна, а те 
марево, яке їм уявляється, є справжньою дійсністю. І можна зрозуміти, що, створюючи світ брехні, де все перетворено на неправду, де реальність відкинута і замінена нереальністю, ангел темряви є вбивцею, тому що жити можна у відносній реальності, і повнота реальності - це вічне життя і Бог. Але в той момент, коли ми за реальність приймаємо нереальне, ми живемо в світі, якого немає, і в цьому світі ми можемо тільки вмирати» (Сурожский, 2004: 261).

Отже, зло - це те, чого Господь не творив, але що виникло як віддалення людської свободи від добра. Коли людина діє не за волею Божою, тоді вона грішить i, можна сказати, перебуває в небутті, бо зло своєї сутності не має. Грішна людина не живе в реальному світі, а живе в ілюзії (породженні недосконалого розуму), в тому світі, який вона сама придумала. Таким чином, зло позбавлене автономного онтологічного статусу. Воно переводиться в площину морально-етичної сфери і напряму залежить від свобідної волі людини та її вибору. Іншими словами, людина є свобідною щодо власного вибору між добром і злом, але саме зло за своєю сутністю не має свободи, оскільки підкоряється свободі вибору і перемагається добром. Тому здолати зло можна лише зсередини людського єства, забираючи його корені найперше з серця людини, змінюючи мислення і мотиви поведінки людини. I одним із суттєвих утруднень у цьому процесі є те, що колосальна кількість душевних та інтелектуальних зусиль людини іде не на власне преображення і розвиток, а на підтримку своїх ілюзій. «Зло не є чимось, або вірніше, воно є лише в той час, коли його роблять». Г. Ніський підкреслює парадоксальність того, хто відкривається злу: людина існує в неіснуючому (Ниський, 2011: 441).

На цьому шляху для людини важливо, з одного боку, намагання зрозуміти промисел Божий і задум Творця щодо неї особисто і людства загалом, а з іншого боку, необхідно підкорятися моральному закону, який допомагає приборкувати злу волю всередині людини. У такому підході відчутний вплив традицій філософії російського космізму в постатях М. Соловйова та П. Флоренського. Згідно з баченням А. Сурозького, маючи внутрішню свободу чинити зло, людина тим самим має змогу відчути стан недосконалості в найрізноманітніших виявах на шляху до досягнення досконалості та відновлення цілісності.

«Для отців Церкви, - як стверджує В. Лоський, - зло є дійсно недолік, порок, недосконалість; не якась там природа, а те, що природі не вистачає, щоб бути досконалою». Зло не існує, а воно є лише залишення буття. Зло є не природою, а станом природи. Таким чином, воно є хворобою, ніби паразитом, існує за рахунок тієї природи, на яку діє. Точніше, зло є деякий стан волі цієї природи; ця воля неправдива щодо Бога. Зло - це бунт проти Бога, тобто позиція особистості. Таким чином зло належитт до перспективи не сутнісної, а особистої. «Світ лежить у злі», - говорить святий апостол і євангеліст Іоан Богослов, зло - це стан, в якому перебуває природа особистих істот, які відвернулися від Бога» (Лосский, 2009: 439).

Дослідник християнської антропології В. Леонов говорить, що «зло - це не самостійна сутність, що виникла коли-небудь через якусь причину, але стан особистості, яка відвернулася від Бога. Не природа, а особистість породжує і генерує зло, коли стає на шлях гріха, котрий є разом із тим і шляхом богоборства» (Леонов, 2016: 163).

А. Сурозький, очевидно, під впливом В. Лоського розглядає зло як певного роду хворобу, як стан, в якому перебуває людська природа, причому у своїй глибині людина залишається доброю, образом Божим. Для пояснення своєї позиції він посилається на слова героя твору Ф. Достоєвського старця Зосими: «Не говори, що люди злі, - люди хороші, а недобрі їх вчинки» (Достоевский, 1970: 268), і сам митрополит резюмує: «Я глибоко переконаний, що людина зла, чи яка творить зло, сама є жертвою (подібно до того, як людина може заразитися певною хворобою) якоїсь сили. Ми можемо ненавидіти зло, ми можемо з жахом думати про те, що велика міра зла оволоділа людиною, але ми не маємо права сказати, що ця людина і зло ототожнюються, що вона - зла» (Сурожский, 2004: 475). Також А. Сурозький в цьому контексті не погоджується 3 думкою Ж.-П. Сартра, що «ми не маємо говорити, що Юда зрадник, тому що він зрадив Христа; він зрадив Христа, тому що був зрадником...». Владика твердить, що ми не маємо права так говорити, тому що це означає, що людина є зло, «за своє досить-таки довге життя, - каже А. Сурозький, - я бачив людей найрізноманітнішого роду і в мирний час, і на війні, і я не зустрічав жодної людини, про кого можна було сказати: він збігається з тим злом, яке робить. У результаті цього, коли ми зустрічаємося зі злом, ми можемо дивитися на того, хто творить зло, як на жертву, яка вимагає співчуття і молитви» (Сурожский, 2004: 475). Тут бачимо власне одну 3 ключових християнських позицій - розділення людини і гріха, зла, яке вона чинить.

Таким чином, зло в особистісному аспекті - це богоборство, особлива світоглядна позиція, котра в природному аспекті проявляє себе як руйнування впорядкованого Богом буття.

Висновки. Отже, в ідеях А. Сурозького щодо тлумачення природи і сутності зла можна виділити кілька аспектів. Найперший той, що зло не наділене онтологічним статусом (загалом ця позиція органічно вплетена в традиційну християнську філософсько-богословську канву із Середньовіччя до ХХ ст.). Природа зла виходить зі свободної волі, найбільше проявляючи себе в моральному житті людини. Людина покликана самореалізовуватися через інтенцію до божественної реальності, долаючи прояви злої волі всередині себе і одночасно тим самим реалізовуючи особистісне творче начало, що неодмінно призводить до зміни світу навколо. У цьому контексті треба згадати ідеї відповідальності людини за світ і природу, а не тільки за себе, про що неодноразового говорить А. Сурозький у своїх бесідах. Моральне видозміна людини (себто обернення зла на добро) відображається на видозміні світу. Про це він говорить в одній з останніх бесід (Сурожский, 2004: 475), наголошуючи, що більшість речей у світі, чи то ядерна зброя, чи ніж у руці, насправді нейтральні. Вся проблема в тому, як ці речі будуть використані і для чого. Справа не в руйнівних засобах, а в страхові, ненависті, злості, злій волі всередині людини. Найгірше зло криється в серці людини. Саме 3 цим має 
боротися людина. Крім цього, А. Сурозький розуміє зло як наслідок викривлення того, що було покликане до буття. У нашому світі є первинне джерело буття, а відповідно, можливостей, а також є викривлена реальність (яка, до прикладу, проявляється як ілюзії у свідомості людини). 3 цієї позиції завданням людини є свідомо взяти на себе відповідальність за те, що діється у світі зла, жорстокості, страждань і через власне вдосконалення, через намагання зрозуміти істинну природу речей і початковий замисел Творця) відновлювати порушену гармонію навколо себе. Одним із механізмів такої роботи є трансформація руйнівних хаотичних енергій у творчі. Людина покликана змінювати світ через переміну себе внутрішньої для осягнення гармонії. Це найважливіше перетворення, до якого вона покликана і яке може змінити світ.

\title{
Список використаних джерел:
}

1. Антоний Митрополит Сурожский. Тело, дух, душа: целостность человеческой личности. Tруды. Kнига вторая. 3-е изд. Москва : Практика, 2014. 978 с.

2. Епікур, Фрагмент 374. URL: https://www.wikiwand.com/uk/Проблема_зла

3. Вальверде К. Философская антропология / пер. с испан. Вдовиной Г. Москва, 2001. 412 с.

4. Григорій Ниський, свт. Творіння : [в 4 т]. Київ, 2011. Т. 1. 623 с.

5. Достоевский Ф.М. Братья Карамазовы. Полн. собр. соч. в. 30 томах. Ленинград : Наука, 1970-1990, т. 14. С. 268.

6. Леонов В. Основы православной антропологии. Москва, 2016. 456 с.

7. Лосский В. Богословие. Очерк мистического богословия Восточной Церкви. Догматическое богословие. Москва : Общество любителей православной литературы Издательство имени святителя Льва, папы Римского, 2009.504 с.

8. Шмеман А. Бог свободы и проблема зла. Беседы на Радио «Свобода». Москва : Издательство ПСТГУ, 2009.

\section{References:}

1. Antonii, mytropolut Surozkyi. (2014). Tielo, duch, dusha: tselostnost chelovecheskoi lichnosti [Body, spirit, soul: the integrity of the human person]. Trudy. Kniga vtoraia. 3-e izd. M.: Praktika [in Russian].

2. Epikur. Fragment 374. URL: www.wikiwand.com/uk/Проблема зла

3. Valverde K. (2001) Filosofskaya antropologiya / per. s ispan. Vdovinoi G. M. [in Russian].

4. Grugoriy Nuskyi, svt. (2011) Tvorinnya : [v 4 T]. K. T. 1. [in Ukrainian].

5. Dostoyevskiy V.M. (1970-1990) Bratiya Karamazovu. Poln. sobr. soch. v. 30 tomah. L.: Nayka, т. 14. [in Russian].

6. Leonov V. (2016) Osnovu pravoslavnoi antropologi. M. [in Russian].

7. Losskiy V. (2009) Bogoslovie. Ocherk misticheskogo bogosloviya Vostochnoi Tserkvi. Dogmaticheskoye bogosloviye. M. : Obshchestvo liybitelei pravoslavnoi literatyru Izdatelstvo imeni svyatutelia Lva, papu Rimskogo. [in Russian].

8. Shmeman A. (2009) Bog svobodu i problema zla. Besedy na radio «Svoboda». M.: Izdatelstvo PSTGY. [in Russian].

\section{DOI https://doi.org/10.51647/kelm.2020.4.1.25}

\section{ЦИГАНИ, СВРЕЇ І СЛОВЕНЦІ В ЕТНОГРАФІЧНИХ ДОСЛІДЖЕННЯХ МИХАЙЛА ЗУБРИЦЬКОГО}

\author{
Микола Тугай \\ аспірант кафедри етнології і археології \\ Прикарпатського нащіонального університету імені Василя Стефаника (Івано-Франківськ, Україна) \\ ORCID ID: 0000-0001-5540-2953
}

\begin{abstract}
Анотація. У статті проаналізовано етнографічні напрацювання українського народознавця отця Михайла Зубрицького стосовно окремих рис матеріальної та духовної культури циган, євреїв та словенців. Метою статті $\epsilon$ опрацювання та аналіз етнографічних матеріалів, в яких виділено окремі етнографічні риси вказаних народів. Методологічна база наукового дослідження базується на міждисциплінарному підході. Використано методи філософського, загальнонаукового та конкретно-історичного характеру, а також метод критичного аналізу документального матеріалу. Вперше проаналізовані етнографічні розвідки отця Михайла Зубрицького, в яких відображено окремі етнографічні особливості окремих народів (євреї, цигани та словенці). У них дослідник занотував особливості родинної та календарної обрядовості, традиційні риси господарської структури та зайнятості, а також житлової забудови та інші риси. Зроблено висновок, що, окрім дослідження бойківського населення, отець Михайло Зубрицький вивчав та зафіксовував традиційні риси духовної та матеріальної культури народів, які проживали поряд з українцями (євреї, цигани) та народу, серед якого значний період часу дослідник сам проживав (словенці).
\end{abstract}

Ключові слова: дослідження, цигани, жиди, словенці, щоденник, Михайло Зубрицький. 